\title{
NILAI-NILAI AKHLAK YANG TERKANDUNG DALAM NOVEL NEGERI 5 MENARA KARYA A. FUADI
}

\author{
Resca Mia Rosadi \\ UIN Sunan Kalijaga Yogyakarta \\ Email: rescamiarosadi5752@gmail.com
}

\begin{abstract}
The background of this research is that education is not only process of knowledge transformation but also aims for the character building and inculcation of noble morals. Education not only be found in schools and in the community but also can be found in literatures such as novels which may serve as learning media. The purpose of this research is to study "The Values of Moral Education" in a literary The Novel of Negeri 5 Menara (The Novel of Land of 5 Towers) by A. Fuadi. "The Novel of Negeri 5 Menara is chosen because it is assumed to contain moral education. This research focuses to reveal the values of moral education in the Novel of Negeri 5 Menara by A. Fuadi. It is to be expected that this research can increase appreciation in apprehend moral education in literary novels.
\end{abstract}

Pembahasan ini dilatar belakangi oleh pemikiran bahwa pendidikan bukan sekedar proses transformasi ilmu, akan tetapi pendidikan merupakan proses pembentukan karakter dan penanaman akhlak mulia. Pendidikan tidak mesti diperoleh di sekolah maupun di lingkungan masyarakat tetapi pendidikan juga bisa berasal dari sumber informasi antara lain novel. Novel tidak mesti berisi fiksi tetapi ada yang berisi pembelajaran tentang nilai-nilai pendidikan akhlak. Novel Negeri 5 Menara karya A. Fuadi diasumsikan mempunyai pesan pembelajaran tentang nilai-nilai pendidikan akhlak. Karena itu, fokus pembahasan ini adalah ingin mengungkapkan nilai-nilai pendidikan akhlak apa saja yang terdapat dalam Novel Negeri 5 Menara karya A. Fuadi.

Keywords: Novel, Sastra, Nilai-nilai Akhlak, Pendidikan, Budi Pekerti 


\section{Pendahuluan}

Akhlak mempunyai kedudukan yang penting dalam kehidupan seseorang, karena kesempurnaan hidup seseorang tergantung pada kebaikan akhlaknya. Jatuh bangunnya seseorang tergantung pada bagaimana akhlaknya. Apabila akhlaknya baik maka ia akan bangun dan sejahtera lahir dan batin, sebaliknya apabila akhlaknya buruk, maka ia akan terperosok serta rusak lahir dan bati. ${ }^{1}$ Dengan demikian maka kejayaan seseorang terletak pada akhlaknya. Akhlak yang baik akan membuat seseorang menjadi tenang, aman, dan tidak akan melakukan perbuatan yang tercela. Sebaliknya akhlak yang buruk akan menyebabkan seseorang menjadi gelisah dan merasa tidak aman sehingga menjadi sorotan bagi sesamanya dan bahkan misalnya mempunyai kecenderungan untuk melanggar akhlak yang berlaku dalam kehidupan masyarakat.

Menurut etimologi "Akhlak" berarti budi pekerti, perangai, tingkah laku, atau tabiat. ${ }^{2}$ Menurut terminologi terdapat beberapa pendapat tentang pengertian "Akhlak". Abu Ali Ahmad bin Muhammad bin Ya'qub yang dikenal dengan Ibnu Maskawaih, wafat tahun $421 \mathrm{H}$., filosof akhlak Islam yang terpengaruh oleh filsafat Yunani, memberikan pengertian bahwa "Akhlak" yaitu "Suatu keadaan bagi jiwa yang mendorong ia melakukan tindakantindakan dari keadaan itu tanpa melalui pikiran dan pertimbangan." Abu Hamid Muhammad bin Muhammad bin Muhammad AlGhazali atau yang dikenal dengan Imam Al-Ghazali, lahir tahun $450 \mathrm{H}$ dan wafat tahun $505 \mathrm{H}$., memberikan definisi bahwa "Akhlak" yaitu "Suatu ungkapan tentang keadaan pada jiwa bagian dalam yang melahirkan bermacam-macam tindakan dengan mudah tanpa memerlukan pikiran dan pertimbangan terlebih dahulu., ${ }^{3}$ Jadi, "Akhlak' menurut terminologi ialah tingkah laku seseorang yang berasal dari dalam jiwanya secara sepontan dan refleks. Dengan tingkah laku yang sepontan dan refleks itu ia secara

\footnotetext{
${ }^{1}$ Bandingkan dengan Septi Khusnul Khotimah, Nilai-nilai Pendidikan Akblak dalam (Skripsi, http://etd.eprints.ums.ac.id/id/eprint/12398,2010).

${ }^{2}$ Mustofa A., Akblak Tasawnf (Bandung: Pustaka Setia, 1997), 11.

${ }^{3}$ Muhammad Rabbi Muhammad Jauhari, Keistimewaan Akblak Islami, terjemahan (Bandung: Pustaka Setia, 2006), 88.
} 
sepontan terdorong untuk memiliki atau melakukan hal-hal yang tergambar sebagai Nilai-nilai Akhlak.

Pada sisi lain karya Sastra mempunyai peran yang penting dalam mentransformasikan nilai-nilai akhlak, etika, dan karakter bagi seseorang. Cerita yang disajikan dalam sebuah karya Sastra baik secara implisit maupun eksplisit selalu berisikan pesan Nilainilai Akhlak misalnya tentang pengharapan pada kejujuran, keberanian dalam menghadapi tantangan, dan nilai-nilai akhlak lainnya. Novel sebagai sebuah karya Sastra merupakan media penting yang berisikan Nilai-nilai Akhlak. Meskipun Novel termasuk salah satu kategori buku suplemen namun Novel dapat berfungsi sebagai bahan pengayaan yang berhubungan dengan Nilai-nilai Akhlak. Novel bisa dijadiakan salah satu perantara untuk mengantarkan seseorang menuju potensi diri yang sesungguhnya, dan sekaligus membentuk bagian-bagian tertentu pada karakter dan kepribadiannya. Novel juga berfungsi sebagai hiburan edukatif. ${ }^{4}$

Novel Negeri 5 Menara karya A. Fuadi adalah salah satu karya Sastra yang menarik untuk dibahas. Novel ini ditulis oleh seorang dengan latar belakang pendidikan Pesantren yang maju dan menyelesaikan sarjana di UNPAD (Universitas Padjadjaran) serta magister di London, Inggris. Novel ini disajikan dengan bahasa yang sederhana dan sarat akan makna dan nilai-nilai akhlak yang memberikan manfaat bagi setiap pembacanya. Hal ini dapat dilihat dari sekelumit kisah dalam Novel ini. Novel ini mengisahkan tentang seorang anak yang bernama Alif Fikri yang berasal dari Bayur, kampung kecil di dekat Danau Maninjau, Padang, Sumatra Barat. Alif Fikri tidak disetujui oleh orang tuanya untuk masuk SMA. Hal itu membuat mimpi Alif Fikri kandas untuk menjadi insinyur atau ahli ekonomi.

Suatu sore Alif Fikri menerima surat dari pamannya yang sedang belajar di Mesir. Pamannya itu menyarankan agar ia melanjutkan sekolah disebuah pondok yang ada di Jawa Timur, Pondok Madani. Dengan berat hati ia memilih untuk mengikuti

${ }^{4}$ Abd. Razak Zaidan, Kamus Istilah Sastra (Jakarta: Balai Pustaka, 2007), 50. 
saran dari pamannya. Setelah mengikuti pendidikan di Pondok Madani, sebuah kalimat bahasa Arab didengar oleh Alif Fikri di hari pertama di Pondok Madani yang mampu mengubah hidupnya. "Mantra" sakti yang diberikan oleh Kiai Rais itu "man jadda wajada", maknanya barang siapa yang bersungguh-sungguh pasti ia berhasil. Kemudian Alif Fikri pun mulai menjalani hari-hari di Pondok Madani dengan ikhlas dan sungguh-sungguh. ${ }^{5}$ Jadi, Nilainilai Akhlak yang dapat dipetik dari kisah di atas ialah kesungguhan dan ketabahan.

Ternyata bagi Alif Fikri kehidupan di Pondok Madani tidak mudah. Banyak hal baru yang harus dijalani, misalnya setiap hari Alif Fikri mempunyai kegiatan menghafal Al-Qur'an, belajar siang malam, harus berbicara dalam bahasa Arab atau Inggris. Ditambah peraturan disiplin yang diterapkan oleh Pondok Madani pada murid. Apabila murid melakukan sedikit kesalahan dan tidak taat pada peraturan akan menerima hukuman yang tidak dapat dibayangkan sebelumnya. Tetapi berkat banyaknya pengalaman yang dijadikan motivasi oleh Alif Fikri, ia dan teman-temannya berhasil menyelesaikan belajarnya di Pondok Madani. Setelah lulus, semua mimpinya yang dulu dirancang di bawah menara menjadi kenyataan. ${ }^{6}$ Maka dari kutipan ini terdapat Nilai-nilai Akhlak yaitu keikhlasan dan kesungguhan.

Jadi, dari uraian latar belakang di atas dapat diketahui bahwa "Nilai-nilai Akhlak" dapat ditemukan karya Sastra. Salah satu di antara karya Sastra itu ialah Novel Negeri 5 Menara yang mengandung "Nilai-nilai Akhlak" yang baik, suatu nilai yang penting bagi kehidupan seseorang untuk kebaikan hidupnya di dunia dan akhirat.

Novel Negeri 5 Menara Karya A. Fuadi dan Nilai-nilai

Akhlak yang Terkandung di Dalamnya

\section{Sekilas Tentang Penulis Novel Negeri 5 Menara}

${ }^{5}$ A. Fuadi, Negeri 5 Menara (Jakarta: Kompas Gramedia, 2013), 11.

${ }^{6}$ A. Fuadi, Negeri 5 Menara, 55.

230 | TAJDID vol. XVI, No. 2, Juni - Desember 2017 
Penulis Novel Negeri 5 Menara, A. Fuadi (Ahmad Fuadi) lahir di Bayur, kampung kecil di pinggir Danau Maninjau pada tahun 1972. A. Fuadi merantau ke Jawa untuk memenuhi permintaan ibunya untuk masuk pondok pesantren yakni Pondok Modern Gontor, Ponorogo, Jawa Timur. Di Pondok Modern Gontor ia bertemu dengan Kiai dan para Ustadz yang menjadi pendidik di sana, yang diberkahi keikhlasan mengajarkan ilmu dunia dan ilmu akhirat. Kiai dan para Ustadz di Pondok Modern Gontor pula yang mengajarkan kepadanya "mantra" sederhana namun merupakan ilmu yang sangat kuat dan mendalam, "man jadda wajada", "siapa yang bersungguh-sungguh ia akan sukses".

Setelah tamat dari Pondok Modern Gontor dia melanjutkan kuliah di UNPAD, Bandung. Setelah lulus kuliah pada Jurusan Hubungan Internasional, dari UNPAD, dia menjadi wartawan majalah Tempo. Tugas jurnalistik pertamanya dijalani dalam peliputan dan reportase dibawah bimbingan para wartawan senior Tempo. Tahun 1999 dia mendapat beasiswa Fullbright untuk melanjutkan kuliah S-2 di School of Media and Public Affairs, George Washington University, USA. Sejak masa itu dia merantau ke Washington DC bersama Yayi, istrinya yang juga wartawan Tempo.

Sambil melaksanakan kuliah dia bersama isterinya menjadi koresponden Tempo dan wartawan VOA (Voice of America). Berita bersejarah misalnya tragedi 11 september dilaporkan berdua bersama isterinya langsung dari Pentagon, White House dan Capitol Hill. Tahun 2004 dia mendapatkan beasiswa Chevening Award untuk belajar di royal Holloway, University of London untuk bidang film dokumenter.

Sampai sekarang A. Fuadi telah mendapatkan 8 (delapan) beasiswa untuk belajar di luar negeri. Dia telah mendapat kesempatan untuk belajar dan tinggal di Kanada, Singapura, Amerika Serikat dan Inggris. Penyuka fotografi ini pernah menjadi Direktur Komunikasi The Nature Conservancy, sebuah NGO

${ }^{7}$ A. Fuadi, Negeri 5 Menara, 40.

TAJDID Vol. XVI, No. 2, Juni - Desember 2017 | 231 
konservasi internasional. Kini, A. Fuadi sibuk menulis, jadi pembicara dan motivator.

Novel Negeri 5 Menara karya A. Fuadi telah mendapatkan beberapa penghargaan, antara lain Nominasi Khatulistiwa Award 2010 dan Penulis Buku Fiksi Terfaforit 2010 versi Anugerah Pembaca Indonesia. ${ }^{8}$

\section{Deskripsi Novel Negeri 5 Menara Karya A. Fuadi}

Pengertian Novel menurut etimologi ialah cerita atau roman. ${ }^{9}$ Sedangkan pengertian Novel menurut terminologi ialah suatu jenis karya cerita yang ditulis berbentuk prosa yang mengandung unsur tokoh, alur, latar rekaan yang menceritakan kehidupan manusia. Karya prosa ini ditulis atas dasar sudut pandang pengarang dan mengandung nilai-nilai hidup yang diolah dengan teknik kisahan dan ragaan yang menjadi dasar konvensi penulisan. ${ }^{10}$ Dapat juga dikatakan bahwa pengertian Novel menurut terminologi ialah sebuah karya imajinatif yang mengisahkan sisi utuh atas problematika kehidupan seseorang atau beberapa orang tokoh. ${ }^{11}$ Jadi, pengertian Novel menurut terminologi ialah sebuah tulisan narasi yang berbentuk prosa yang menggambarkan suatu karakter atau kejadian dari seorang tokoh atau beberapa orang tokoh yang bersifat imajinatif atau yang terkadang menggambarkan cerita sejarah.

Sejalan dengan pengertian Novel tersebut maka Novel Negeri 5 Menara karya A. Fuadi adalah cerita atau roman yang berbentuk prosa yang mengandung unsur tokoh, alur, dan latar rekaan yang menceritakan perjalanan hidup tokohnya. Ceritanya bersifat imajinatif namun berdasarkan kisah nyata penulisnya yang mengisahkan problematika kehidupan tokohnya. Novel ini mengandung nilai-nilai hidup yang diolah dengan teknik kisahan dan ragaan yang menjadi dasar penulisannya.

${ }^{8}$ A. Fuadi, Negeri 5 Menara, 421.

'John M. Echols dan Hassan Shadaly, Kamus Inggris Indonesia, En English Indonesian Dictonary (Jakarta: Gramedia Pustaka Utama, 2007), 398.

${ }^{10}$ Abd. Razak Zaidan, Kamus Istilab Sastra, 136.

${ }^{11}$ E. Kosasih, Apresiasi Sastra Indonesia (Jakarta: Penerbit Nobel Edumedia, 2008), 46. 
Bila dilihat dari fungsi dan manfaatnya, maka Novel Negeri 5 Menara karya A. Fuadi mempunyai fungsi dan manfaat yang bersifat rekreatif. Dengan membaca Novel ini maka seseorang dapat memperoleh hiburan. Bisa juga mempunyai fungsi dan manfaat yang bersifat didaktif yaitu dengan membaca Novel ini, seseorang dapat memperoleh pengetahuan dan pelajaran tentang nilai-nilai akhlak yang ada di dalamnya. Dari sini dapat terbangkitkan kreativitas dan emosi orang yang membacanya untuk berbuat sesuatu yang positif, baik untuk dirinya sendiri maupun untuk orang lain. ${ }^{12}$

Namun bila dilihat dari sudut pandang objek formalnya, yakni dari sudut pandang mana Novel itu dilihat maka Novel Negeri 5 Menara karya A. Fuadi dapat digolongkan sebagai Novel didaktik karena berisikan cerita yang mengandung pembelajaran. Atau Novel kunci atau sejarah karena menggambarkan peristiwa yang bersifat sejarah (historis) dalam bentuk rekaan dengan penggantian nama pelaku dan tempat berlangsungnya peristiwa. Atau Novel tokohan karena menampilkan orang yang memainkan peran sebagai tokoh dengan pemberian watak, sifat, atau kebiasaan. Penokohan dapat dilakukan melalui teknik kisahan dan ragaan. Watak dan sifat tokoh itu terlihat dalam lakuan pisik (tindakan dan ujaran) dan lakuan rohani (renungan atau pikiran). ${ }^{13}$

Novel Negeri 5 Menara adalah karya A. Fuadi yang diterbitkan pertamakali oleh Gramedia, Jakarta, pada tahun 2009. Yang dibahas di sini terbitan tahun 2013 dengan tebal halaman berjumlah 405 halaman tidak termasuk halaman tambahan. Novel ini bergenre roman, edukasi, dan religi. Novel ini bercerita tentang kehidupan enam santri dari enam daerah yang berbeda yang menuntut ilmu di Pondok Madani (PM) Ponorogo, Jawa Timur. Mereka adalah:

Alif Fikri Chaniago dari Maninjau.

Raja Lubis dari Medan.

Said Jufri dari Surabaya.

${ }^{12}$ E. Kosasih, Apresiasi Sastra Indonesia, 4-5.

${ }^{13}$ Abd. Razak Zaidan, Kamus Istilab Sastra, 137.

TAJDID Vol. xvi, No. 2, Juni - Desember 2017 | 233 
Dulmajid dari Sumenep.

Atang dari Bandung.

Baso sholahuddin dari Gowa.

Mereka sama-sama sekolah, belajar, dan berasrama dari kelas 1 (satu) sampai kelas 6 (enam). Kian hari mereka semakin akrab dan memiliki kegemaran yang sama yaitu duduk di bawah menara Pondok Madani. Dari kegemaran yang sama mereka menyebut diri mereka Shâhib al-Manârah.

\section{Sinopsis Novel Negeri 5 Menara Karya A. Fuadi}

Kisah dalam Novel Negeri 5 Menara karya A. Fuadi merupakan perpaduan antara historis dan fiksi yang bersifat fenomenologis. Dikatakan historis karena ceritanya mengisahkan sejarah perjalanan seorang anak muda yang melakukan perantauan dalam rangka mencari ilmu pengetahuan. Perantauan anak muda ini dimulai dari kampung halamannya di Sumatera Barat sampai ke Jawa Timur lalu Jawa Barat dan Luar Negeri. Dikatakan fiksi karena nama pelaku dan beberapa tempat yang menjadi setting ceritanya disamarkan atau diganti namanya sehingga seolah-olah fiktif, padahal ceritanya merupakan kisah nyata pelakunya yang merupakan penulisnya. Berikut ini adalah sinopsis atau ringkasan Novel Negeri 5 Menara karya A. Fuadi.

Dalam Novel Negeri 5 Menara karya A. Fuadi dikisahkan bahwa Alif Fikri adalah remaja kelahiran Bayur, Bukittinggi yang semasa kecilnya hobi berburu durian runtuh bersama ayahnya dan bermain bola di sawah berlumpur. Setelah lulus dari Madrasah ia ingin melanjutkan pendidikannya ke SMA Bukittinggi. Tetapi keinginannya untuk masuk SMA justru bertentangan dengan pendapat amaknya yang menginginkan Alif Fikri untuk tetap bersekolah di Sekolah Agama atau Pesantren. Alif Fikri bimbang. Surat pun datang dari Pak Etek Gindo, paman Alif Fikri. Pak Etek Gindo menyarankannya untuk mencoba bersekolah Agama di tempat yang dulunya pernah menjadi tempat sekolah Pak Etek Gindo. Tetapi Alif Fikri masih asing dengan tempat itu. Dengan setengah hati mengikuti saran pamannya, Alif Fikri dengan diantarkan oleh ayahnya pergi ke pulau seberang yakni pulau Jawa untuk belajar di Pondok Madani, di Jawa Timur. Justru disinilah dia mulai mengerti makna hidup yang sebenarnya. Life begin at 
Pondok Madani. Di hari kedatangan mereka ke Pondok Madani, Alif Fikri dan ayahnya, dan juga peserta didik baru yang lain diajak untuk ikut mengelilingi beberapa tempat di Pondok Madani.

Belajar di hari pertama, kepada Alif Fikri diberikan sebuah kalimat, lebih dari sebuah kumpulan kata-kata, yang nantinya akan menjadi kompas kehidupan mereka. Man Jadda Wajada. Siapa yang bersungguh-sungguh akan berhasil! Dia mengagumi kebudayaan di Pondok Madani yang mengharuskan setiap penduduk (santri) Pondok Madani untuk berbicara hanya dengan menggunakan bahasa Arab atau Inggris, tidak dengan bahasa yang lain. Apabila ketahuan melanggar, maka hukumannya adalah menjadi jâsus atau mata-mata. Siapa yang menjadijasus, mereka harus mencari pelanggar lain di Pondok Madani, lalu dilaporkan kepada Mahkamah. Itu pula yang pernah dirasakan oleh Alif Fikri ketika menjadi jasus.

Di Pondok Madani, Alif Fikri bertemu dan berteman baik dengan Raja Lubis dari Medan, Atang dari Bandung, Said Jufri dari Surabaya, Baso dari Gowa dan Dulmajid dari Madura. Mereka berenam kerap berkumpul di menara samping masjid. Maka dari itu mereka sering disebut Sâbib al-Manârah, orang yang punya menara. Di bawah menara Pondok Madani pula mereka beranganangan akan suatu benua impian, benua yang entah bagaimana caranya bisa mereka raih. Alif Fikri melihat awan-awan itu bagaikan sebuah Benua Amerika, sedangkan Raja melihatnya sebagai Benua Eropa, Atang melihatnya Benua Asia dan Baso melihat itu semua sebagai Benua Afrika. Sedangkan Said dan Dulmajid melihatnya sebagai negara Indonesia.

Meskipun bahagia berada di Pondok Madani, Alif Fikri tidak bisa menyembunyikan rasa irinya kepada Randai, sparring partnernya sekaligus sahabatnya yang berada di ITB (Institut Teknologi Bandung). Bahkan Alif Fikri memiliki gagasan untuk keluar dari Pondok Madani dan mengikuti ujian persamaan agar dapat masuk ITB. Pikirannya makin kacau ketika harus merelakan Baso untuk pulang kampung ke Gowa. Alif Fikri semakin resah. Mereka tidak tahu akan menjadi apa kelak. Yang mereka tahu 
hanyalah: Jangan pernah meremehkan impian, walau setinggi apapun. Sungguh Tuhan Maha Mendengar.

Man Shabara Zhafira. Siapa yang bersabar akan beruntung. Jangan risaukan penderitaan hari ini, jalani saja dan lihat apa yang akan terjadi di depan. Karena yang dituju bukan sekarang, tetapi ada yang lebih besar dan prinsipil, yaitu menjadi manusia yang telah menemukan misinya dalam hidup. ${ }^{14}$

Nilai-nilai Akhlak dalam Novel

Negeri 5 Menara Karya A. Fuadi

Nilai-nilai Akhlak dan Sumbernya

dalam Novel Negeri 5 Menara Karya A. Fuadi

Secara garis besar pembagian akhlak ada dua yaitu pertama akhlak yang baik (al-akblaq al-karimah) dan kedua akhlak yang buruk (al-akblaq al-mazmumah). Akhlak yang baik misalnya berbuat adil, jujur, sabar, pemaaf, dermawan, dan amanah; sedangkan akhlak yang buruk misalnya adalah perbuatan zalim, berdusta, pemarah, pendendam, kikir, dan curang.

Nilai-nilai Akhlak dalam Novel Negeri 5 Menara karya A. Fuadi terdiri atas akhlak yang baik dan akhlak yang buruk. Dalam pembahasan ini akan difokuskan pada Nilai-nilai Akhlak yang baik dan terpuji. Hal ini dapat dilihat dari keseluruhan tema cerita yang terdapat dalam Novel Negeri 5 Menara karya A. Fuadi. Jumlah tema sebanyak 45 buah. Semua jumlah tema itu merupakan term yang berisikan cerita positif. Misalnya dapat dilihat dari tema pertama "Pesan dari Masa Silam", tema kesepuluh "Sarung dan Kurban", tema keduapuluh "Berlian dari Belgia", tema ketigapuluh "Parlez. Vour. Prancais?", dan tema keempatpuluh "Shaolin Temple". ${ }^{15}$ Nilai-nilai Akhlak yang baik dan terpuji dalam novel Negeri 5 Menara sejalan dengan pengertian akhlak.

Pengertian "akhlak" yang berasal dari bahasa Arab "khuluq", kata jamaknya "khuluqun atau khilqun", secara etimologi berarti budi pekerti, perangai, tingkah laku, atau tabiat. Kata akhlak lebih luas pengertiannya dari pada kata etika atau moral yang juga sering

${ }^{14}$ Dani Setiadi, sinopsis Negeri Lima Menara (Mei 2012).

${ }^{15}$ A. Fuadi, Negeri 5 Menara, vii-viii.

236 | TAJDID Vol. XVI, No. 2, Juni - Desember 2017 
dipakai dalam bahasa Indonesia. Kata akhlak meliputi segi yang sangat mendalam dari tingkah laku yang bersifat lahir dan batin.

Kata akhlak satu akar kata dengan "khalqun" yang berarti kejadian dan juga satu akar kata dengan "khaliq" yang berarti Pencipta yakni Allah, dan satu akar kata dengan "makbluq" yang berati ciptaan. Perumusan pengertian kata akhlak timbul sebagai usaha yang memungkinkan adanya hubungan baik antara Khalik dan makhluk dan sebaliknya antara makhluk dan Khalik. ${ }^{16}$

Kata "akhlak" dapat juga dilihat dari sisi lain bahwa ia merupakan isim mashdar dari kata "akblaqa - yukbliqu - ikblâqan", sesuai dengan timbangan (wazan tsulâtsy mazî̀d) af'ala - yuf'ilu if'âlan, artinya perangai (al-sajiyyah), kelakuan; tabiat; watak dasar (althabî'ab), kebiasaan; kelaziman (al-'adab), peradaban yang baik (almurû'ah), dan agama (al-dîn). Ada juga pendapat bahwa kata "akhlaq" merupakan isim jâmid atau isim ghair mustaq, yaitu isim yang tidak memiliki akar kata, tetapi kata itu memang demikian adanya. ${ }^{17}$ Jadi, dapat disimpulkan bahwa pengertian akhlak dari segi etimologi adalah budi pekerti, adat kebiasaan, perangai, muru'ah (peradaban). Atau dengan kata lain akhlak adalah segala sesuatu yang sudah menjadi tabiat kebiasaan.

Pengertian "akhlak" menurut terminologi sebagaimana yang dikemukakan oleh Ibn Miskawaih (w. 421 H/1030 M) dalam kutipan Abuddin Nata ialah

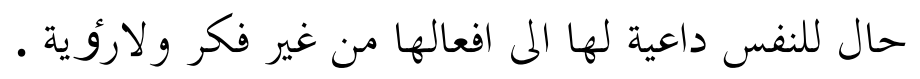

"Sifat yang tertanam dalam jiwa yang mendorongnya untuk melakukan perbuatan tanpa memerlukan pemikiran dan pertimbangan". 18

Sementara itu pengertian akhlak menurut Imam Al-Ghazali (1059-1111 M), ialah

\footnotetext{
${ }^{16}$ Rosihon Anwar, Akidah Akblak (Bandung: Pustaka Setia, 2008), 205.

${ }^{17}$ Abuddin Nata, Akblak Tasawuf dan Karakter Mulia (Jakarta: RajaGrafindo Persada, 2014), 1.

${ }^{18}$ Abuddin Nata, Akblak. Tasawnf dan Karakter Mulia, 3.
} 


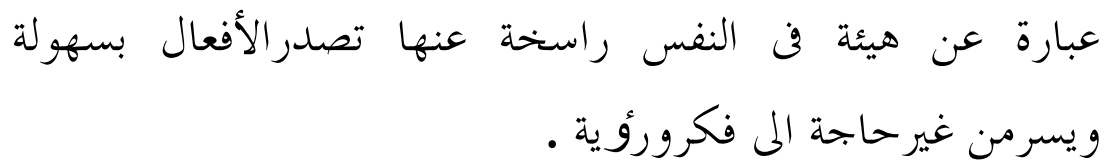

"Sifat yang tertanam dalam jiwa yang menimbulkan berbagai macam perbuatan dengan gampang dan mudah, tanpa memerlukan pemikiran dan pertimbangan". 19

Sejalan dengan pendapat di atas, oleh Ibrahim Anis dalam Mu'jam al-Wasith sebagaimana dikutip dalam Abuddin Nata dikemukakan bahwa pengertian akhlak ialah

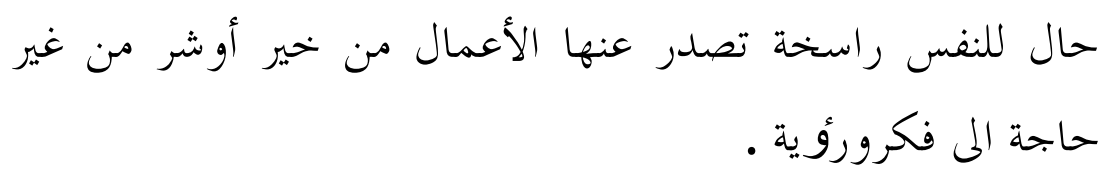

"Sifat yang tertanam dalam jiwa, yang dengannya labir bermacammacam perbuatan, baik atau buruk, tanpa membutubkan pemikiran dan pertimbangan".

Selanjutnya pengertian akhlak secara singkat dapat dilihat di dalam Dairatul Ma'ârifialah

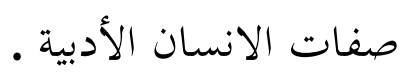

"Sifat-sifat manusia yang terdidik.". 1

Jadi, pengertian akhlak menurut terminologi ialah kebiasaan baik yang tertanam dalam jiwa manusia sehingga menjadi kepribadiannya. Kebiasaan itu timbul dari dalam diri pelakunya yang dilakukan dengan sungguh-sungguh, mudah, dan tanpa pemikiran namun dengan penuh kesadaran tanpa paksaan.

Akhlak yang baik didefinisikan sebagai perilaku yang baik, namun perilaku yang baik itu harus diulang-ulang. Perilaku yang dilakukan hanya sekali atau sesekali tidak cukup untuk dikatakan sebagai akhlak yang berarti perbuatan baik. Seseorang dapat

${ }^{19}$ Abuddin Nata, Akblak Tasawnf dan Karakter Mulia, 3.

${ }^{20}$ Abuddin Nata, Akblak Tasawnf dan Karakter Mulia, 3.

${ }^{21}$ Abuddin Nata, Akblak Tasawnf dan Karakter Mulia, 3.

238 | TAJDID Vol. XVI, No. 2, Juni - Desember 2017 
dikatakan baik akhlaknya jika timbul dengan sendirinya suatu perbuatan yang didorong oleh motivasi yang kuat dan dilakukan tanpa banyak pertimbangan dan sering diulang, sehingga terkesan sebagai suatu keharusan untuk dilakukan. Jika hal itu dilakukan secara terpaksa bukan merupakan refleksi dari akhlak yang baik.

Adapun sumber Nilai-nilai Akhlak dalam Novel Negeri 5 Menara karya A. Fuadi bersumber dari ajaran Islam. Ini dapat dilihat dari sebagian besar cerita dalam Novel ini yang berisikan cerita pendidikan, pembelajaran, ketaatan, ketauladanan, dan sejenisnya dengan sumber rujukan yang akrab dikenal dalam ajaran Islam. Hal ini dapat ditangkap dari ilustrasi kutipan cerita dalam Novel Negeri 5 Menara karya A. Fuadi sebagai berikut: “...Menurut Kiai kami, pendidikan PM tidak membedakan agama dan nonagama. Semuanya satu dan semuanya berbubungan...".22 Dalam kutipan lain bahwa "Selama ini pengalaman menunjukean kalau kemampuan hapalanku sangat lemah. Padahal beberapa pelajaran penting sangat erat berbubungan dengan bapalan. Untuk, Al-Qur'an, Hadits dan beberapa mata pelajaran, mau tidak mau hapalan harus bagus". 23 Jadi, dapat disimpulkan dari kutipan ini bahwa basis pelajaran agama Islam sangat kuat sebagai dasar nilai-nilai akhlak di sini. Maka sumber Nilai-nilai Akhlak dalam Novel Neger 5 Menara karya A. Fuadi adalah ajaran Islam.

\section{Nilai-nilai Akhlak yang Terpuji dan Ruang Lingkupnya dalam Novel Negeri 5 Menara Karya A. Fuadi}

Nilai-nilai Akhlak yang terpuji dalam Novel Negeri 5 Menara karya A. Fuadi maksudnya ialah nilai-nilai akhlak yang baik dan positif atau akhlak Islami. Nilai-nilai akhlak yang terpuji ini adalah akhlak yang dimiliki oleh seseorang yang selalu sejalan dengan akal, kemanusiaan, dan bersumber dari jaran Islam. Nilai-nilai akhlak yang terpuji adalah perbuatan yang dilakukan dengan mudah, disengaja, mendarah daging, dan sebenarnya yang didasarkan pada ajaran Islam. Nilai-nilai akhlak yang terpuji itu karena berdasarkan Islam yang universal maka ia juga bersifat universal, namun dalam

${ }^{22}$ A. Fuadi, Negeri 5 Menara, 35.

${ }^{23}$ A. Fuadi, Negeri 5 Menara, 381

TAJDID Vol. xvi, No. 2, Juni - Desember 2017 | 239 
rangka penjabarannya diperlukan bantuan pemikiran manusia dan kesempatan sosial yang terkandung dalam nilai-nilai akhlak, etika, dan moral. ${ }^{24}$

Nilai-nilai akhlak yang terpuji itu karena didasarkan pada nilainilai Islam maka ia mengakui adanya nilai-nilai yang universal sebagai dasar bentuk akhlak, di samping itu mengakui juga nilainilai lokal dan temporal sebagai penjabaran atas nilai-nilai yang universal tersebut. Misalnya menghormati kedua orang tua - ayah dan ibu - ialah akhlak yang bersifat universal. Adapun bagaimana cara menghormati kedua orang tua itu dapat dilaksanakan sesuai penjabaran hasil pikiran manusia yang dipengaruhi oleh situasi dan kondisi di mana orang itu tinggal. Bagi orang Jawa misalnya menghormati kedua orang tua dengan cara sungkem, bagi orang Sunda menghormati kedua orang tua dengan cara mencium tangannya waktu berjabat tangan, dan bagi orang Sumatera menghormati kedua orang tua dengan cara memeliharanya hidup bersama satu rumah. ${ }^{25}$

Adapun ruang lingkup Nilai-nilai Akhlak yang terpuji yang berdasarkan ajaran Islam sama dengan ruang lingkup ajaran Islam itu sendiri. Namun secara garis besar ruang lingkup Nilai-nilai Akhlak yang terpuji dalam kajian tentang Novel Negeri 5 Menara karya A. Fuadi dapat dibagi ke dalam tiga bagian yaitu: 1 . Nilai-nilai Akhlak terhadap Allah, 2. Nilai-nilai Akhlak terhadap manusia, 3. Nilai-nilai Akhlak terhadap lingkungan. Namun dalam pembahasan disini dibatasi pada 1. Nilai-nilai Akhlak terhadap Allah, dan 2. Nilai-nilai Akhlak terhadap manusia.

\section{Nilai-nilai Akhlak Terhadap Allah}

\section{Berserah Diri Kepada Allah}

Salah satu dari prinsip aqidah Islam adalah berserah diri kepada Allah dengan cara bertauhid yaitu menjadikan Allah sebagai satu-satunya tempat bersandar. Dalam lingkup pembahasan tentang Nilai-nilai Akhlak dalam bentuk nilai aqidah banyak

${ }^{24}$ A. Zainuddin dan Muhammad Jamhari, Al-Islam 2: Muamalah dan Akblak (Bandung: Pustaka Setia, 1999), 78.

${ }^{25}$ Abuddin Nata, Akblak Tasawnf dan Karakter Mulia, 126.

240 | TAJDID Vol. XVI, No. 2, Juni - Desember 2017 
dijumpai dalam Novel Negeri 5 Menara karya A. Fuadi antara lain sebagai berikut:

\section{Berdoa}

Rasulullah selalu mengajarkan kepada para sahabatnya dan terutama kepada para umatnya bahwa sebelum melakukan aktivitas hendaknya berdoa terlebih dahulu. Berdoa dalam istilah agama adalah permohonan hamba kepada Tuhan yakni Allah agar memperoleh anugerah pertolongan dan pemeliharaan, baik buat si pemohon maupun pihak lain. Permohonan tersebut harus lahir dari lubuk hati yang terdalam disertai dengan ketundukan dan pengagungan hanya kepada Allah. ${ }^{26}$

Berdoa sebagaimana yang diajarkan oleh Rasulullah itu sejalan dengan kisah yang terdapat dalam Novel Negeri 5 Menara karya A. Fuadi. Ini dapat dilihat dari kutipan dalam Novel itu "Maka selesai sholat Asar berjamaah, aku terpekur lebih lama dan memanjatkan doa sebagai seorang jasus yang "teraniaya" karena belum menemukan pelanggar aturan. Aku dengan kbusuk memohon petunjuk kepada Allah memudahkan misi ini sehingga kehidupanku kembali tenang dan damai". ${ }^{27}$

Pada kutipan itu dapat dilihat bahwa dalam Novel Negeri 5 Menara karya A. Fuadi tergambarkan sebuah nilai Akhlak yaitu berdoa, memohon segala sesuatu hanya kepada Allah. Dalam kutipan tersebut digambarkan bahwa sang tokoh yaitu Alif Fikri dengan khusu' memohon kepada Allah agar dimudahkan segala kesusahan dan musibah yang menimpa dirinya.

Siapapun sebagai manusia tentu pernah mengalami kesusahan dalam hidup yang semua itu merupakan ujian dan cobaan dari Allah. Sesungguhnya ketika kesulitan itu datang maka Allah-lah sebaik-baik penolong dan janganlah sampai tergoda untuk meminta pertolongan kepada selain Allah. Hal ini sesuai dengan firman Allah yaitu:

${ }^{26}$ M. Quraish Shihab, Dikutip melalui blog Abdul Ghafur (2006), 177.

${ }^{27}$ A. Fuadi, Negeri 5 Menara, 82.

TAJDID Vol. xvi, No. 2, Juni - Desember 2017 | 241 


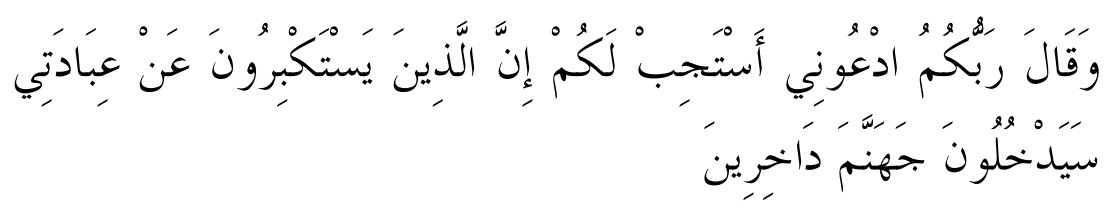

"Dan Tuhanmu berfirman: "berdoalah kepada-Ku, niscaya akan Kuperkenankan bagimu. Sesunggubnya orang-orang yang menyombongkan diri dari menyembah-Ku akan masuk neraka jahanam dalam keadaan bina dina." (Q.S. Al-mukmin: 60).

Ayat tersebut memperkuat kutipan dalam Novel Negeri 5 Menara karya A. Fuadi di atas bahwa setiap umat Islam diperintahkan untuk berdoa hanya kepada Allah. Memohon pertolongan dan menyerahkan segala urusan hanya kepada-Nya. Perlu diketahui bahwa berdoa adalah cara yang ampuh untuk menanamkan Nilai-nilai Akhlak pada setiap umat.

\section{Tawakkal}

Setelah berdoa dan berusaha telah dikerjakan maka selanjutnya adalah tawakkal. Tawakkal ialah menyerahkan semua hasil usaha yang telah dilakukan kepada Allah. Masalah tawakkal dapat dilihat dalam Novel Negeri 5 Menara karya A. Fuadi sebagaimana dalam kutipan ini: "Ya Allah telab aku sempurnakan usahaku dan doaku kepada-Mu. Sekarang semua aku serabkan kepada-Mu. Aku tawakeal dan ikblas. Mudabkan lab ujianku besok. Amin". ${ }^{28}$

Dalam kutipan tersebut digambarkan bahwa Alif Fikri, sang tokoh dalam kisah Novel Negeri 5 Menara karya A. Fuadi, telah berusaha dan bekerja keras untuk mengatasi berbagai kesulitannya dalam belajar dan untuk mencapai cita-citanya. Namun hasilnya tetap diserahkan hanya kepada Allah dalam arti tawakkal kepadaNya. Secara harfiah tawakkal berarti menyerahkan diri. Menurut Harun Nasution yang dikutip oleh Abuddin Nata dalam bukunya Akhlak Tasawnf, bahwa tawakkal adalah menyerahkan diri kepada qada dan keputusan Allah. ${ }^{29}$

Dalam al-Qur'an Allah berfirman:

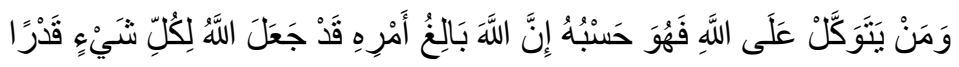

${ }^{28}$ A. Fuadi, Negeri 5 Menara, 200.

${ }^{29}$ Abuddin Nata, Akblak Tasawnf dan Karakter Mulia, 202.

242 | TAJDID Vol. XVI, No. 2, Juni - Desember 2017 
"Dan barang siapa yang bertawakeal kepada Allah niscaya Allah akan mencukupkan keperluannya. Sesunggubnya Allab melaksanakan urusan yang dikehendaki-Nya. Sesungghnya Allah telah Mengadakan ketentuan bagi tiap-tiap sesuatu." (Q.S. At-Talaaq: 3).

Ayat tersebut memperkuat kutipan dalam Novel Negeri 5 Menara karya A. Fuadi di atas tentang tawakkal, bahwa barang siapa yang percaya kepada Allah dalam menyerahkan semua urusan kepada-Nya maka Allah akan mencukupkan segala keperluannya. Jadi dalam hubungannya dengan tulisan ini adalah ayat tersebut menjelaskan bahwa tawakkal secara tidak langsung merupakan contoh Nilai-nilai Akhlak terhadap Allah.

\section{Taat dan Patuh Kepada Allah}

Nilai-nilai Akhlak selanjutnya adalah taat dan patuh kepada Allah. Taat dan patuh kepada Allah artinya menjalankan segala perintah Allah dan menjauhi segala larangan-Nya. Dalam Novel Negeri 5 Menara karya A. Fuadi juga ditemukan Nilai-nilai Akhlak tentang ketaatan dan kepatuhan kepada Allah.

\section{Menjauhi Perbuatan Dosa}

Salah satu tanda bagi seorang yang beriman adalah senantiasa menjalankan perintah Allah dan menjauhi semua yang dilarangNya. Karena seorang hamba yang beriman akan selalu takut melakukan perbuatan dosa. Bahkan didalam al-Qur'an Allah telah menjanjikan tempat yang mulia di akhirat bagi orang yang menjauhi perbuatan dosa.

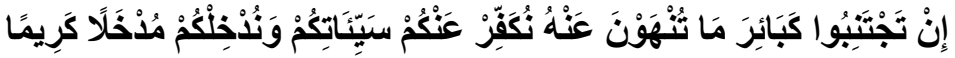

"Iika kamu menjaubi dosa-dosa besar diantara dosa-dosa yang dilarang kamu mengerjakannya, niscaya Kami hapus segala kesalaban-kesalahan (dosa-dosamu yang kecil) dan Kami masukkan kamu ketempat yang mulia (syurga).” (Q.S. An-Nisa': 31).

Di dalam Novel Negeri 5 Menara karya A. Fuadi oleh penulis juga telah disampaikan pesannya kepada siapapun khususnya kepada saudara seiman untuk senantiasa menjauhi perbuatan yang menimbulkan dosa. Itu antara lain dapat dilihat dalam kutipan 
dialog ini, "Melihat yang bukan mubrim bisa mengbilangkan bafalan Alquranku, kata baso dengan suara rendah. Mukanya ditundukkan ke stang sepeda". 30

Kutipan tersebut menjelaskan bahwa Baso menjaga pendangan matanya dari melihat kepada yang bukan mahramnya, karena hal tersebut merupakna perbuatan maksiat. Dia takut perbuatan maksiat tersebut dapat menghilangkan hafalan alQur'annya. Karena salah satu penyebab yang menghalangi dan menyulitkan hapalan al-Qur'an adalah maksiat.

Dalam kutipan lain yang sejalan dengan kutipan ini ialah: "banya amak sendiri yang berani angkat tangan dan berkata, "kita disini adalah pendidik dan ini tidak mendidik. Kemana muka kita disembunyikan dari Allah Yang Maha Melihat. Ambo tidak man ikut bersekongkol dalam ketidakjujuran ini. 31

Dari kutipan pada Novel tersebut dapat dilihat bahwa betapa mulianya sikap amak yang berani menantang keputusan mayoritas masyarakat. Mereka yang dalam hal ini saling bersekongkol dalam hal ketidakjujuran, tapi amak dengan tegas menantang persekongkolan tersebut karena merupan perbuatan dosa. Jadi dalam Novel Negeri 5 Menara karya A. Fuadi terdapat Nilai Akhlak tentang menjauhi perbuatan dosa.

\section{Ibadah Kepada Allah}

"Ibadat" atau "ibadah" secara etimologi adalah sebuah kata yang diambil dari bahasa Arab, 'abada-ya'budu yang berarti mengesakan, tunduk, taat. ${ }^{32}$ Dalam terminologi bahasa Indonesia sebagaimana yang terdapat dalam Kamus Bahasa Indonesia "ibadah" memiliki arti yaitu: (a) Perbuatan atau pernyataan bakti terhadap Allah atau Tuhan yang didasari oleh peraturan agama, (b) Segala usaha lahir batin yang sesuai dengan perintah agama yang harus

${ }^{30}$ A. Fuadi, Negeri 5 Menara, 128.

${ }^{31}$ A. Fuadi, Negeri 5 Menara, 139.

${ }^{32} \mathrm{Al}-$ 'Ab Luweis Ma'lûf, al-Munjid fì al-Lughah wa al-A'lâm (Beirut: Dâr alMasyrik, 1975), 483. 
dituruti pemeluknya, (c) Upacara yang berhubungan dengan agama. ${ }^{33}$

Pengertian Ibadah yang baik dan lengkap adalah apa yang dikemukakan oleh Syaikh al-Islam Ibnu Taimiyah. Dia mengatakan, Ibadah adalah suatu istilah yang mencakup segala sesuatu yang dicintai oleh Allah dan diridhai-Nya, baik berupa perkataan maupun perbuatan, yang tersembunyi (batin) maupun yang nampak (lahir). Maka shalat, zakat, puasa, haji, berbicara jujur, menunaikan amanah, berbakti kepada kedua orang tua, menyambung tali kekerabatan, menepati janji, memerintahkan yang ma'ruf, melarang dari yang munkar, berjihad melawan orangorang kafir dan munafiq, berbuat baik kepada tetangga, anak yatim, orang miskin, ibnu sabil (orang yang kehabisan bekal di perjalanan), berbuat baik kepada orang atau hewan yang dijadikan sebagai pekerja, memanjatkan do'a, berdzikir, membaca al-Qur'an dan lain sebagainya adalah termasuk bagian dari ibadah. Begitu pula rasa cinta kepada Allah dan Rasul-Nya, takut kepada Allah, inabah (kembali taat) kepada-Nya, memurnikan agama (amal ketaatan) hanya untuk-Nya, bersabar terhadap keputusan (takdir)Nya, bersyukur atas nikmat-nikmat-Nya, merasa ridha terhadap qadha atau takdir-Nya, tawakkal kepada-Nya, mengharapkan rahmat (kasih sayang)-Nya, merasa takut dari siksa-Nya dan lain sebagainya itu semua juga termasuk bagian dari ibadah kepada Allah. $^{34}$

\section{Nilai-nilai Akhlak yang termaksud dalam nilai ibadah ialah:}

\section{Shalat}

Shalat merupan wujud ketaatan seorang hamba kepada Penciptanya. Shalat merupakan ibadah wajib yang harus dikerjakan oleh umat Islam yang sudah baligh. Allah berfirman:

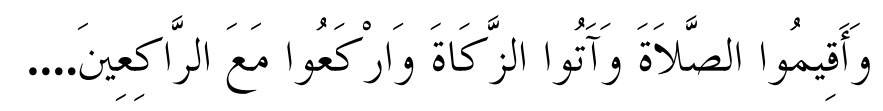

${ }^{33}$ Tim Penyusun, Kamus Babasa Indonesia (Jakarta: Pusat Bahasa Departemen Pendidikan Nasional, 2008), 536

${ }^{34}$ Wikipedia.

TAJDID Vol. XVI, No. 2, Juni - Desember 2017 | 245 
"Dan dirikanlah sholat dan tunaikanlah zakat dan ruku' lah beserta orang-orang yang ruku'.” (Q.S. Al-Baqarah: 43).

Ayat tersebut secara jelas memerintahkan kepada setiap umat Islam untuk melaksanakan Ibadah shalat. Nilai shalat terletak pada peranannya sebagai jalan utama untuk mengenal Allah. Maka jika ingin lebih mengenal dan mendekatkan diri kepada Allah, laksanakanlah shalat.

Dalam Novel Negerei 5 Menara karya A. Fuadi terdapat Nilai Akhlak yang disampaikan oleh penulis berupa pesan tentang kewajiban melaksanakan shalat. Pesan itu dapat dilihat dalam kutipan sebagai berikut: "Shalat Maghrib di masjid jami' dihadiri seluruh penduduk sekolah. Karena hampir semua orang hadir, kecuali yang sakit atau pura-pura sakit, waktu seperempat jam setelah shalat dimanfaatkan untuk memberi maklumat penting bagi semua warga., 35

Kutipan dalam Novel tersebut diatas dapat dipahami bahwa seluruh penduduk sekolah menghadiri shalat Maghrib berjamaah di Masjid Jami', kecuali yang sakit sehingga berhalangan untuk ikut shalat berjamaah dimasjid, akan tetapi tidak menggugurkan kewajibannya untuk mendirikan shalat.

Disamping shalat fardhu, dalam Novel Negeri 5 Menara karya A. Fuadi juga terdapat Nilai-nilai Akhlak tentang Ibadah shalat sunnah yaitu shalat tahajud. Dalam kutipan berikut disebutkan: "Aku membentang sajadah dan melakukan shalat tahajud. Diakbir rakaat, aku benamkan kesejadah sebuah sujud yang panjang dan lama., 36

Pada kutipan tersebut di atas digambarkan bahwa sang tokoh dalam kisah Novel Negeri 5 Menara karya A. Fuadi rajin mendirikan shalat sunnah tahajjud dan berserah diri kepada sang Pencipta. Ini memberikan pesan berupa Nilai Akhlak bahwa shalat sunat tahajud, di samping shalat fardhu, menanamkan rasa ketaatan, ketundukan, kedisiplinan, kerendahan hati, kesabaran, dan keikhlasan dalam diri seseorang. Maka melaksanakan shalat tahajud selayaknya dibiasakan pada diri sendiri.

\section{Bersyukur}

${ }^{35}$ A. Fuadi, Negeri 5 Menara, 70.

${ }^{36}$ A. Fuadi, Negeri 5 Menara, 197.

246 | TAJDID Vol. XVI, No. 2, Juni - Desember 2017 
Allah berfirman:

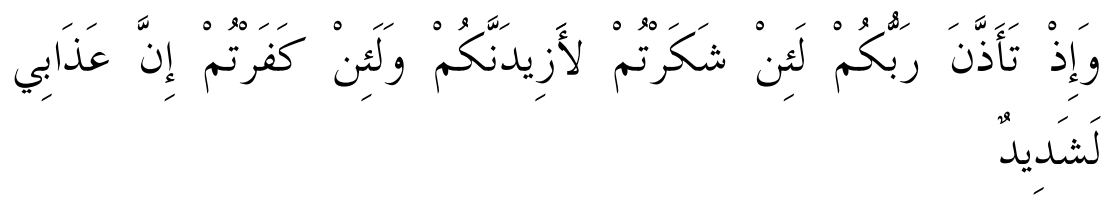

"Dan (ingatlah juga), tatkala Tubanmu memaklumkan; sesunggubnya jika kamu bersyukur, pasti Kami akan menambah nikmat kepadamu, dan jika kamu mengingkari nikmat-Ku, maka sesunggubnya azab-Ku sangat pedih.” (Q.S. Ibrahim: 7).

Dari ayat di atas dapat disimpulkan bahwa salah satu Nilai Akhlak yang baik ialah bersyukur kepada Allah. Menurut ayat itu bahwa sudah sepantasnya bagi seseorang khususnya umat Islam untuk mensyukuri segala nikmat yang diberikan oleh Allah dan dengan bersyukur kadar keimanan seseorang akan bertambah semakin kuat. Dengan besyukur akan mengingatkan seseorang bahwa semua yang dimilikinya adalah titipan Allah.

Ini ada kesejalanan dengan kisah yang dapat dilihat dalam Novel Negeri 5 Menara karya A. Fuadi. Kisah tentang keharusan bersyukur dapat dimaksudkan sebagai Nilai Akhlak. Hal ini antara lain dapat dilihat pada kutipan sebagai berikut: "Tiba-tiba Said mengangkat tangan dengan gembira, menggumamkan alhamdulillab dan berteriak yes, sambil tangannya ditarik. kebawah, layaknya striker habis mencetak gol tunggal di injury time. 37

Ini adalah refleksi rasa syukur dari kawan Alif Fikri yang bernama Raja setelah lulus dalam ujian akhir di Pondok Madani sebagaimana diceritakan oleh Alif Fikri dalam Novel Negeri 5 Menara karya A. Fuadi. Kata Alif Fikri:

"Sebelum tidur kami bertemu di depan kamar. "alhamdulillah, syukurlah kawan, aku akbirnya dapat juga tadi. Coba kalau tidak, bisa kebawa mimpi malam ini", kata Raja dengan muka sumringah.,38 "Artinya LULUS. Alhamdulillah. Seperti banyak teman lainnya, aku

${ }^{37}$ A. Fuadi, Negeri 5 Menara, 71.

${ }^{38}$ A. Fuadi, Negeri 5 Menara, 80.

TAJDID vol. XvI, No. 2, Juni - Desember 2017 | 247 
segera sujud syukur di aula, berterima kasih kepada Allah untuk. kelulusan ini. ${ }^{39}$

Jadi, menurut Alif Fikri bahwa Raja, sahabatnya di Pondok Madani, memanjatkan rasa syukur kepada Allah karena lulus dalam ujian akhir yang dilaluinya.

Dari beberapa kutipan tersebut dapat dianalisa bawa dalam Novel Negeri 5 Menara karya A. Fuadi ada penyampaian pesan untuk selalu bersyukur sebagai Nilai Akhlak. Sekecil apapun nikmat yang didapat maka wajib disyukuri. Karena hanya demikian maka nikmat itu akan ditambah oleh Allah. Nikmat itu bisa saja misalnya merupakan kesuksesan menuntut ilmu di masa berikutnya di tempat lain.

\section{Akhlak terhadap Manusia}

\section{Akhlak Terhadap Diri Sendiri}

Menuntut ilmu merupakan kewajiban bagi setiap umat Islam, baik laki-laki maupun perempuan. Karena pentingnya menuntut ilmu maka sebagian ulama ada yang mengatakan bahwa menuntut ilmu itu seperti jihad di jalan Allah. Hal ini senada dengan kisah dalam Novel Negeri 5 Menara karya A. Fuadi. Dalam Novel ini dapat dilihat bahwa ketika ibunda Alif Fikri memberi pesan kepadanya dalam sebuah dialog, sebagaimana dalam kutipan berikut: "Baik-baik dirantau urang, nak, amak, percaya ini jalan untuke membela agama. Belajar ilmu agama sama dengan berjihad di jalan Allah, kata beliau." 40

Dalam kutipan tersebut dijelaskan bahwa amak atau ibunda Alif Fikri memberi nasihat kepada Alif Fikri tentang pentingnya belajar atau menuntut ilmu terutama ilmu agama (Islam). Ia mengibaratkan belajar ilmu agama sama dengan berjihad di jalan Allah. Sebagian ulama mengatakan bahwa berjihad dengan ilmu lebih utama dari pada berjihad dengan senjata. Bahkan Allah menjanjikan akan mengangkat derajat orang-orang yang berilmu, sebagaimana firman-Nya dalam al-Qur'an:

${ }^{39}$ A. Fuadi, Negeri 5 Menara, 395.

${ }^{40}$ A. Fuadi, Negeri 5 Menara, 14.

248 | TAJDID Vol. XVI, No. 2, Juni - Desember 2017 


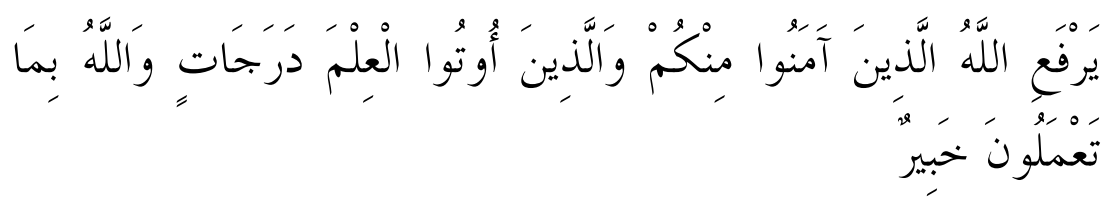

"Allah akan meninggikan orang-orang yang beriman diantaramu dan orang-orang yang diberi ilmu pengetabuan beberapa derajat. Dan Allah mengetabui apa yang kamu kerjakan.” (Q.S. Al-Mujadalah: 11).

Dalam Novel ini ada kisah lain yang menunjukkan pentingnya belajar dan menuntut ilmu agama (Islam) sebagaimana kutipan berikut: "Bujukan mereka agar tetap tinggal di kampung telah kukalabkan dengan argumen berbahasa Arab yang terdengar gagah, 'uthlubil ilma walau bisshin', artinya, tuntutlah ilmu walau babkan jaub sampai ke negeri Cina." ${ }^{, 41}$

Dari kutipan kisah dalam Novel tersebut terlihat adanya penyampaian sebuah pesan tentang semangat menuntut ilmu terutama ilmu agama (Islam). Jarak yang jauh tidak menjadi penghalang dalam upaya menuntut ilmu. Karena dalam Islam sendiri telah ada perintah untuk menuntut ilmu kemana saja, walaupun jauh tempatnya, misalnya saja waulupun hingga ke negeri Cina. Cina menjadi contoh karena letaknya yang jauh dari negeri Arab tempat kelahiran Islam. Ilmu adalah suatu yang sangat mulia sebab ilmu adalah pemberian Allah bagi manusia yang menjadi perantara untuk menjadi insan yang bertakwa. Giat belajar merupakan konsekuensi terhadap diri dari rasa tanggung jawab sebagai khalifah di bumi.

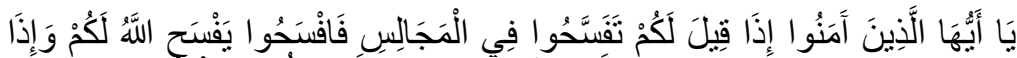

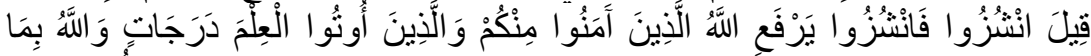

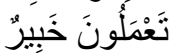

"Hai orang-orang yang beriman apabila kamu dikatakan kepadamu: "berlapang-lapanglab dalam majelis", maka lapangkanlah, niscaya Allah akan memberi kelapangan kepadamu. Dan apabila dikatakan "berdirilah kamu" maka berdirilah niscaya Allah akan meninggikan orang-orang yang beriman diantaramu dan orang-orang yang diberi ilmu pengetabuan beberapa

${ }^{41}$ A. Fuadi, Negeri 5 Menara.

TAJDID Vol. XVI, No. 2, Juni - Desember 2017 | 249 
derajat. Dan Allah maha mengetahui apa yang kamu kerjakan." (Q.S. AlMujadalah: 11).

Dalam Novel Negeri 5 Menara karya A. Fuadi juga ditampilkan contoh bagaimana giat belajar, antara lain sebagaimana pada kutipan ini:

"Kecuali Baso, dia tidak ikut olabraga, dan sekarang dia masih saja memelototi beberapa kertas soal ujian, sambil sibuk bolak balik melibat buku pelajaran. Berkali-kali dia mengangguk-angguk sambil tersenyum sendiri. Aku tidak habis pikir, dengan kemampuan photogarapic memorynya, dia tidak perlu cemas dengan hasil ujian, apalagi harus mencek. seperti ini. ",42

Pada bagian ini Novel Negeri 5 Menara karya A. Fuadi menampilkan sosok Baso yang giat belajar. Hal ini terbukti dengan kesediaan dirinya untuk meninggalkan olahraga hanya untuk menyibukkan dirinya dalam belajar. Bahkan teman-temanya merasa heran dan takjub terhadap sikapnya. Jadi, kemauan untuk menuntut ilmu dan semangat belajar sebagaimana yang ditunjukkan oleh Baso dalam Novel Negeri 5 Menara menunjukkan adanya akhlak terhadap diri sendiri.

\section{Akhlak Terhadap Keluarga}

Islam telah meletakkan kedudukan orang tua dengan mulia. Allah telah menegaskan di dalam al-Qur'an bahwa anak harus senantiasa berbuat baik kepada orang tua dan orang tua adalah pembawa berkah dalam kehidupan anaknya.

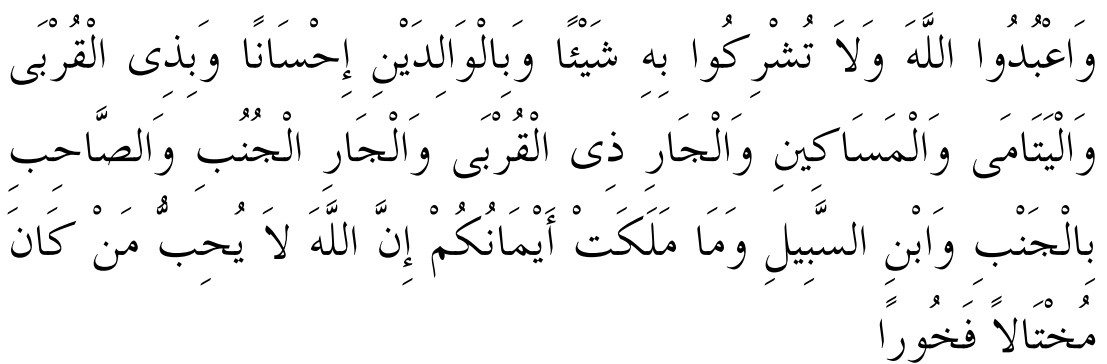

"Sembablah Allah dan janganlah kamu mempersekutukanNya dengan sesuatupun dan berbuat baiklah kepada dua orang ibu bapa, karib kerabat,

42A. Fuadi, Negeri 5 Menara, 206.

250 | TAJDID Vol. XVI, No. 2, Juni - Desember 2017 
anak-anak yatim, orang-orang miskin, tetangga yang dekat dan tetangga yang jaub, dan teman sejawat, ibnu sabil dan hamba sabayamu. Sesunggubnya Allah tidak menyukai orang-orang yang sombong dan membangga-banggakan diri.” (Q.S. An-Nisa: 36).

Ayat tersebut menjelaskan bahwa perintah berbakti kepada orang tua posisinya setelah perintah untuk beribadah kepada Allah. Hal ini menggambarkan betapa pentingnya berbakti kepada orang tua. Dalam Novel Negeri 5 Menara karya A. Fuadi terdapat beberapa contoh yang disampaikan oleh Alif Fikri tentang berbakti kepada orang tua antara lain sebagaimana kutipan ini: "Sebelum meninggalkan rumah aku cium tangan amak, sambil minta doa dan minta ampun atas kesalabanku. Tangan kurus amak mengusap kepalaku. "A3 Dalam kutipan lain dikatakan bahwa "begitulah aku diajarkan untuk selalu berbakti kepada orang tua dan yang lebih utama adalah ibu. Amak. bagiku adalah junjungan dan bos besar. Beliau juga penguasa pintu surga bagiku." 44

Kutipan Novel diatas menjelaskan tentang rasa bakti Alif Fikri terhadap orang tuanya terutama ibunya. Di dalam Islam kedua orang tua memiliki kedudukan yang mulia dan tinggi dengan kedudukan tersebut bahkan Allah melarang sekedar berkata " $a b$ " kepada mereka (Al-Isra': 23). Perkataan "ab" saja termasud dosa apalagi membentak. Maka dari itu siapapun harus senantiasa berdoa kepada Allah agar diberi umur yang panjang untuk berbakti kepada orang tuanya.

Jadi, kisah untuk berbakti kepada kedua orang tua dalam Novel Negeri 5 Menara karya A. Fuadi sejalan dengan tuntunan ajaran Islam. Kisah itu menunjukkan adanya Nilai Akhlak dalam Novel itu berupa akhlak terhadap keluarga.

\section{Akhlak Terhadap Masyarakat}

Akhlak terhadap masyarakat meliputi akhlak terhadap tetangga dan akhlak terhadap orang lain. Tetangga ialah orang yang paling dekat tempat tinggalnya dengan seseorang yang tidak mempunyai

${ }^{43}$ A. Fuadi, Negeri 5 Menara, 70.

44A. Fuadi, Negeri 5 Menara, 141. 
pertalian darah atau pertalian persaudaraan, dan mungkin tidak sesuku atau tidak satu agama. Orang lain ialah selain tetangga dan selain saudara atau kaum kerabat. ${ }^{45}$

Sejalan dengan ini, maka dalam Novel Negeri 5 Menara karya A. Fuadi, akhlak terhadap masyarakat ialah akhlak terhadap masyarakat dan orang lain yang ada di sekitar lingkungan Alif Fikri ketika belajar di Pondok Madani. Masyarakat di sini adalah para santri Pondok Madani sebagaimana dapat dilihat dari kutipan ini: "Shalat Magrib di Masjid Jami" dihadiri selurub penduduk sekolah. Karena hampir semua orang hadir - kecuali yang sakit atau pura-pura sakit waktu seperempat jam setelah shalat dimanfaatkan untuk memberikan maklumat penting bagi semua warga". 46

Selain itu yang dimaksud masyarakat ialah teman Alif Fikri dan para guru atau asatiz. Para teman Alif Fikri ketika belajar di Pondok Madani ialah Raja, Said, Dulmajid, Atang, dan Baso. Alif Fikri sering berkumpul bersama mereka dalam berbagai kegiatan khususnya belajar. Waktu berkumpul yang sering mereka manfaatkan ialah menjelang shalat Magrib dan tempat yang sering digunakan ialah di bawah menara Masjid Jami'. Hal ini dapat dilihat dari ungkapan Alif Fikri dalam Novel Negeri 5 Menara karya A. Fuadi sebagaimana kutipan berikut:

"Seperti kata orang bijak, penderitaan bersamalah yang menjadi semen dari pertemanan yang lekat. Sejak menjadi jasus keamanan pusat, aku, Raja, Said, Dulmajid, Atang, dan Baso lebih sering berkumpul dan belajar bersama. Kalau lelah belajar, kami membahas kemungkinan untuk bebas dari jerat pengawasan keamanan. ${ }^{47}$

Sedangkan para guru atau asatiz yang harus dihormati oleh Alif Fikri sebagai wujud perbuatan akhlaknya yang mulia diantaranya ialah Ustaz Salman, Ustaz Surur, Ustaz Faris, Ustaz Jamil, Ustaz Badil, Ustaz Karim, Ustaz Torik, Ustaz Khaidir, dan Kiayi Rais (semuanya nama samaran). ${ }^{48}$ Akhlak terhadap mereka ialah berbuat baik dan bersikap terpuji kepada mereka. Sikap ini

\footnotetext{
${ }^{45}$ M. Ali Hasan, Tuntunan Akblak (Jakarta: Bulan Bintang,1978), 73.

${ }^{46}$ A. Fuadi, Negeri 5 Menara, 70.

${ }^{47}$ A. Fuadi, Negeri 5 Menara, 92.

${ }^{48}$ A. Fuadi, Negeri 5 Menara, 110-119, 124, 246.
}

252 | TAJDID Vol. XVI, No. 2, Juni - Desember 2017 
sejalan dengan anjuran Islam yang membuat ketetapan untuk memuliakan mereka, tidak mengganggu dan tidak menyusahkan mereka.

Kemudian ulama membagi tetangga menjadi tiga macam yaitu pertama, tetangga satu agama (Islam) yang mempunyai hubungan tali kekeluargaan. Terhadap tetangga semacam ini mempunyai tiga hak, hak sebagai tetangga, hak sebagai muslim, dan hak sebagai kerabat. Kedua, tetangga satu agama saja. Terhadap tetangga semacam ini mempunyai dua hak, hak sebagai muslim dan hak sebagai tetangga. Ketiga, tetangga selain muslim atau beda agama. Terhadap tetangga semacam ini hanya mempunyai satu hak yaitu hak sebagai tetangga.

Bila dilihat dari pembagian tetangga menurut ulama tersebut maka masyarakat yang ada di lingkungan Alif Fikri di Pondok Madani merupakan tetangga satu agama yaitu sama-sama muslim. Terhadap tetangga semacam ini ada dua hak akhlak yang harus dilakukan kepada mereka yaitu hak sebagai muslim dan hak sebagai tetangga. Dari kutipan dalam Novel Negeri 5 Menara karya A. Fuadi di atas dan elaborasi tentang kutipan itu, dapat disimpulkan bahwa dalam Novel Negeri 5 Menara karya A. Fuadi terdapat Nilai-nilai Akhlak terhadap masyarakat.

\section{Kesimpulan}

Dari pembahasan di atas maka dapat diambil kesimpulan bahwa Nilai-nilai Akhlak ialah sesuatu yang berharga berupa pelajaran, pengajaran, dan pendidikan yang ditransformasikan untuk proses perubahan sikap dan tingkah laku seseorang dalam usaha mendewasakan mereka. Nilai-nilai Akhlak ialah proses pengembangan kemampuan sikap dan tingkah laku seseorang ke arah yang baik sehingga memiliki kemampuan sosial dan perkembangan individual secara mumpuni. Nilai-nilai Akhlak dalam Novel Negeri 5 Menara karya A. Fuadi ialah akhlak yang baik dan positif yang Islami. Akhlak yang terpuji ini dimiliki oleh orang yang sejalan dengan akal, kemanusiaan, dan bersumber dari ajaran Islam. Akhlak yang terpuji adalah perbuatan yang dilakukan dengan mudah, disengaja, mendarah daging, dan sebenarnya yang 
didasarkan pada ajaran Islam. Akhlak yang terpuji itu meliputi akhlak terhadap Allah dan ahklak terhadap manusia.

\section{Daftar Pustaka}

-------, Metode Penelitian Pendidikan: pendekatan Kuantitatif, Kualitatif dan R\&D., (Bandung: Alfabeta, 2009).

A., Mustafa, Akhlak Tasawuf, (Bandung: Pustaka Setia, 1997).

Anonim, Alquran dan terjemah, (CV. Penerbit Diponegoro, Jawa Barat, 2009).

Anwar, Rosihon, Akidah Akhlak, Bandung: Pustaka Setia, 2008).

Arifin, Tajul, (2013), Teori dan Teknik Pembuatan Desain Penelitian, (Makalah, Juni 2013).

Burhan, B. Metodologi Penelitian Sosial Dan Ekonomi, (Jakarta: Kencana Prenada Media Group, 2013).

E. Kosasih, Apresiasi Sastra Indonesia, (Jakarta: Penerbit Nobel Edumedia, 2008).

Echols, John M., dan Hassan Shadaly, Kamus Inggris Indonesia, En English Indonesian Dictonary, (Jakarta: Gramedia Pustaka Utama, 2007).

Fuadi, A., Negeri 5 Menara, (Jakarta: Kompas Gramedia, 2013). Hasan, M. Ali, Tuntunan Akhlak, (Jakarta: Bulan Bintang, 1978). Jauhari, Muhammad Rabbi Muhammad, Keistimewaan Akhlak Islami, terjemahan, (Bandung: Pustaka Setia, 2006).

Khotimah, Septi Khusnul, (2010), Nilai-nilai pendidikan Akhlak. (Skripsi, http://etd.eprints.ums.ac.id/id/eprint/12398, 2010).

Ma'lûf, Al-'Ab Luweis, al-Munjid fî al-Lughah wa al-A'lâm, (Beirut: Dâr al-Masyrik, 1975).

Nata, Abuddin, Akhlak Tasawuf dan Karakter Mulia, (Jakarta: RajaGrafindo Persada, 2014).

Sugiyono, Memahami Penelitian Kualitatif, (Bandung: Alfabeta, 2013).

Tim Penulis, Buku Panduan Skripsi FITK IAIN STS Jambi, (Jambi: 2012).

Tim Penyusun, Kamus Bahasa Indonesia, (Jakarta: Pusat Bahasa Departemen Pendidikan Nasional, 2008).

Zaidan, Abd. Razak, Kamus Istilah Sastra, Jakarta: Balai Pustaka, 2007).

Zainuddin, A., dan Muhammad Jamhari, Al-Islam 2: Muamalah dan Akhlak, (Bandung: Pustaka Setia, 1999). 